\title{
THE ROLE OF SOCIAL ASSISTANCE IN REDUCING POVERTY AND INEQUALITY IN ASIA AND THE PACIFIC
}

Armando Barrientos

NO. 62

September 2019
ADB SUSTAINABLE DEVELOPMENT WORKING PAPER SERIES 

ADB Sustainable Development Working Paper Series

\section{The Role of Social Assistance in Reducing Poverty and Inequality in Asia and the Pacific}

Armando Barrientos

No. 62 | September 2019
Armando Barrientos is professor emeritus in poverty and social justice at the Global Development Institute, the University of Manchester. 
(c) 2019 Asian Development Bank

6 ADB Avenue, Mandaluyong City, 1550 Metro Manila, Philippines

Tel +632632 4444; Fax+6326362444

www.adb.org

Some rights reserved. Published in 2019.

Printed in the Philippines.

Publication Stock No. WPS190423-2

DOI: http://dx.doi.org/10.22617/WPS190423-2

The views expressed in this publication are those of the authors and do not necessarily reflect the views and policies of the Asian Development Bank (ADB) or its Board of Governors or the governments they represent.

ADB does not guarantee the accuracy of the data included in this publication and accepts no responsibility for any consequence of their use. The mention of specific companies or products of manufacturers does not imply that they are endorsed or recommended by ADB in preference to others of a similar nature that are not mentioned.

By making any designation of or reference to a particular territory or geographic area, or by using the term "country" in this document, $A D B$ does not intend to make any judgments as to the legal or other status of any territory or area.

This work is available under the Creative Commons Attribution 3.0 IGO license (CC BY 3.0 IGO)

https://creativecommons.org/licenses/by/3.0/igo/. By using the content of this publication, you agree to be bound by the terms of this license. For attribution, translations, adaptations, and permissions, please read the provisions and terms of use at https://www.adb.org/terms-use\#openaccess.

This CC license does not apply to non-ADB copyright materials in this publication. If the material is attributed to another source, please contact the copyright owner or publisher of that source for permission to reproduce it. ADB cannot be held liable for any claims that arise as a result of your use of the material.

Please contact pubsmarketing@adb.org if you have questions or comments with respect to content, or if you wish to obtain copyright permission for your intended uses that do not fall within these terms, or for permission to use the ADB logo.

Corrigenda to ADB publications may be found at http://www.adb.org/publications/corrigenda.

Notes:

In this publication, "\$" refers to United States dollars.

ADB recognizes "Vietnam" as Viet Nam. 


\section{CONTENTS}

TABLES, FIGURES, AND BOX iv

ACKNOWLEDGMENTS Vi

ABBREVIATIONS

EXECUTIVE SUMMARY Vii

I. SOCIAL PROTECTION AND ADB 1

II. CHALLENGES IN SOCIAL PROTECTION IN ASIA AND THE PACIFIC 2

A. Poverty and Inequality 2

B. Demographic Change 2

C. Inclusive Growth 4

D. Environmental Change $\quad 5$

III. SOCIAL PROTECTION IN ASIA: TAKING STOCK 6
A. Spending
6
B. Programming
6
C. Reach
8
D. Distribution

IV. LOOKING AHEAD: STRENGTHENING SOCIAL ASSISTANCE AND THE ROLE OF ADB 11

A. Equity and Social Assistance: Tax-Transfer Systems 12

B. Aligning Objectives and Programming: Social Investment 14

C. Improving Technical and Implementation Capacity 15

D. Sustainable Financing 16

$\begin{array}{ll}\text { V. CONCLUSION } & 18\end{array}$

$\begin{array}{ll}\text { APPENDIX } & 19\end{array}$ 


\section{TABLES, FIGURES, AND BOX}

\section{Tables}

1 Global Estimates of Children in Extreme Poverty by Region 4

2 Social Assistance Contribution to Poverty and Inequality Reduction 11

\section{Figures}

1 Poverty Headcount Rate, East Asia 2

2 Poverty Headcount Rate, South Asia 3

3 Social Security and Welfare Spending, Asia and the Pacific $\quad 7$

4 Reach of Social Insurance and Social Assistance by Region 9

5 Social Protection and Social Assistance Expenditure Reaching the Poor, 2015

6 The Impact of Taxes and Transfers on the Gini Coefficient 12

7 Impact of Taxes and Transfers on Poverty 13

8 Social Assistance Expenditure 17

Box

Do Social Investment Programs Pay for Themselves? 


\section{ACKNOWLEDGMENTS}

Gratitude is extended to Sri Wening Handayani, principal social development specialist, and Wendy Walker, chief, Social Development Thematic Group, Sustainable Development and Climate Change Department, Asian Development Bank. 


\section{ABBREVIATIONS}

ADB - Asian Development Bank

DMC - developing member country

GDP - gross domestic product

PRC - People's Republic of China

\section{NOTE}

In this paper, "\$” refers to US dollars. 


\section{EXECUTIVE SUMMARY}

This working paper analyzes the role and contribution of social assistance to reducing poverty and inequality and supporting inclusive growth in Asia and the Pacific. It is based on an assessment of current trends in social assistance provision against the main policy challenges faced by developing member countries (DMCs) in the region, informed by the international experience.

It is divided into three main sections. First, it reviews long-standing and emerging challenges to social protection in Asia and the Pacific: poverty and inequality, demographic change, inclusive growth, and environmental change. Second, it reviews social assistance provision, covering spending, programming, reach, and distribution. Third, it examines key issues shaping the development of social assistance: equity, social investment, and sustainable financing.

Acknowledging the expansion of social assistance provision in the region over the last 2 decades, the working paper identifies the main challenges. The region has been remarkably successful in reducing extreme poverty, but a large share of the population remains mired in moderate poverty. According to World Bank estimates, 322 million people in East and South Asia lived on less than $\$ 1.90$ per day, 1.2 billion people on less than $\$ 3.20$ per day, and 2.2 billion people on less than $\$ 5.50$ per a day in 2013 . Moreover, there have been several demographic changes. Recent economic growth, in contrast to the 1980s and 1990s, has not been as inclusive, with inequality rising in the more populous DMCs. Environmental change provides an additional parameter in the design of social assistance.

A brief assessment of current social assistance provision reveals emerging welfare institutions in Asia and the Pacific. Spending on social protection shows an upward trend, from an unweighted average of just under $4.0 \%$ of gross domestic product in 2003-2005 to 5.3\% in 2015. The main focus of social protection expansion is social assistance, in line with trends in Latin America and Africa. However, the distribution of spending is skewed toward nonpoor population groups. With variation across DMCs, social assistance has indeed reduced poverty and inequality.

Three key issues are likely to shape the future development of social assistance in the region. First, tax-transfer systems are the most effective public instrument to advance equity, but as currently designed in DMCs, they have marginal effects on equality and poverty. Social assistance has an important role in improving the distributional effects of tax-transfer systems in the region. Second, the global expansion of social assistance has emphasized its social investment role, but the protective role of social assistance has been dominant in the region. A rebalancing of social assistance protection and social investment roles will be key to the development of social assistance. Third, strengthening social assistance will require resource mobilization as well as sustainable and stable financing. 



\section{SOCIAL PROTECTION AND ADB}

1. Strategy 2030 of the Asian Development Bank (ADB) acknowledges the role of social protection investments in contributing to inclusive growth. 'By addressing poverty, inequality, and vulnerability, social protection helps ensure that growth is sustained, sustainable, and reaches all sectors of the population.

2. The ADB social protection operational plan defined social protection as "the set of policies and programs designed to reduce poverty and vulnerability by promoting labor market functioning, diminishing people's exposure to risks, and enhancing their capacity to protect themselves against hazards and the interruption and loss of income." It confirmed that investment in social protection improves the productive capacity of individuals, contributing to inclusive, equitable, and sustainable economic growth. It also set out an agenda for ADB in this important policy area. ${ }^{3}$

3. The 1997-1998 Asian financial crisis provided a reminder that investment in social protection was urgently needed in the region. The expansion of social protection that followed, in developing member countries (DMCs) like Indonesia and the Republic of Korea, lent much-needed resilience to their economies. Indeed, comprehensive social protection institutions established in high-income countries in the region during the second half of the last century are credited with helping foster growth, social and economic development, and inclusion. ${ }^{4}$ In the last decade, more DMCs have taken steps to strengthen their social protection policies and institutions in response to rising social demand and challenges posed by global economic trends, including the global financial crisis. ${ }^{5}$ Throughout the region, economic growth and structural transformation have also encouraged investment in effective social protection institutions and policies, ${ }^{6}$ as in the large economies of the People's Republic of China (PRC) and India.

4. From a global perspective, the expansion of social protection and assistance is overdue. Early social assistance expansion in Latin America and the Caribbean has consolidated into stable institutions. ${ }^{7}$ Emerging institutions in Africa point to a rapid expansion in social assistance provision over the next decades. ${ }^{8}$ Further, social protection policies have gained prominence in international development policy, as demonstrated by the Sustainable Development Goals; investment in social protection - particularly social assistance-is now a global policy objective. ${ }^{9}$ Yet much work lies ahead to address long-standing challenges in growing social protection, and new challenges are emerging from the recent patterns of growth, including rising inequality and environmental change.

\footnotetext{
ADB. 2018. Strategy 2030: Achieving a Prosperous, Inclusive, Resilient, and Sustainable Asia and the Pacific. Manila.

ADB. 2013. Social Protection Operational Plan 2014-2020. Manila. pp. 1.

3 "[B] etween 1996 and 2012, ADB approved 202 stand-alone loans, grants, and technical assistance on social protection with a total value of $\$ 3.3$ billion. This represents $2.3 \%$ of ADB's total portfolio during the period." Ibid.

4 Organisation for Economic Co-operation and Development (OECD). 2008. Growing Unequal? Income Distribution and Poverty in OECD Countries. Paris.

5 A. Bauer, and M. Thant, eds. 2010. Poverty and Sustainable Development in Asia: Impacts and Responses to the Global Economic Crisis. Manila.

6 ADB. 2013. The Social Protection Index: Assessing Results for Asia and the Pacific. Manila.

7 United Nations Economic Commission for Latin America and the Caribbean. 2015. Inclusive Social Development: The Next Generation of Policies for Overcoming Poverty and Reducing Inequality in Latin America and the Caribbean. Santiago de Chile.

8 V. Monchuk. 2014. Reducing Poverty and Investing in People: The New Role of Safety Nets in Africa. Washington, DC: World Bank.

9 M. Honorati, U. Gentilini, and R. Yemtsov. 2015. The State of Social Safety Nets 2015. Washington, DC: World Bank Group.
} 


\section{CHALLENGES IN SOCIAL PROTECTION IN ASIA AND THE PACIFIC}

\section{A. Poverty and Inequality}

5. Economic growth in Asia and the Pacific in the 1980s and 1990s led to a rapid reduction of extreme poverty in the region, helping the region advance toward achieving many Millennium Development Goals. ${ }^{10}$ The percentage of the population living in extreme poverty (i.e., $\$ 1.90$ per day) declined from 80.40\% in 1981 to 3.68\% in 2013 in East Asia, and from 54.70\% to 14.65\% in South Asia during the same period (Figures 1 and 2). Moderate poverty rates also fell, although less dramatically, consistent with population groups who had been living in extreme poverty now pushed into moderate poverty. Today, these trends are most apparent in South Asia, where $51.9 \%$ of the population lives below $\$ 3.20$ per day, while $83.1 \%$ lives below $\$ 5.50$ per day. According to the World Bank, in 2013, 322 million people in East Asia and South Asia still lived on less than $\$ 1.90$ per day; 1.2 billion people on less than $\$ 3.20$ per day, and 2.2 billion people on less than $\$ 5.50$ per day.

\section{B. Demographic Change}

6. DMCs are also facing rapid population aging, a consequence of the combined effects of extended life expectancy and reduced fertility. According to ADB, the population over the age of 65 years in the region will number 923 million by 2050. In the PRC, the population over age 65 years reached 200 million in 2015, and India will reach the same number by 2030. A rise in the share of older people requires

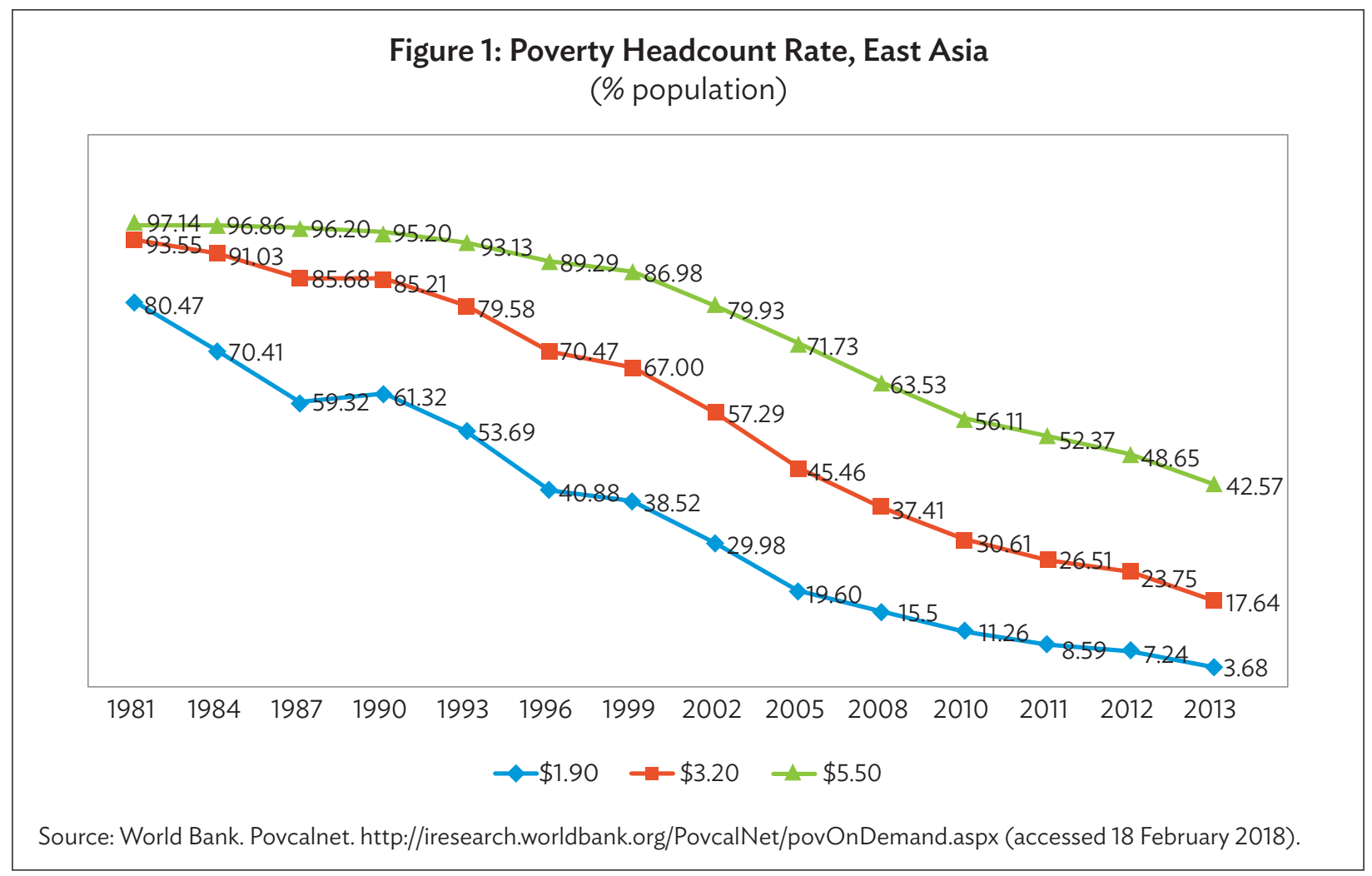

10 S. Chen and M. Ravallion. 2013. More Relatively-Poor People in a Less Absolutely-Poor World. The Review of Income and Wealth. 59 (1). pp. 1-28. 


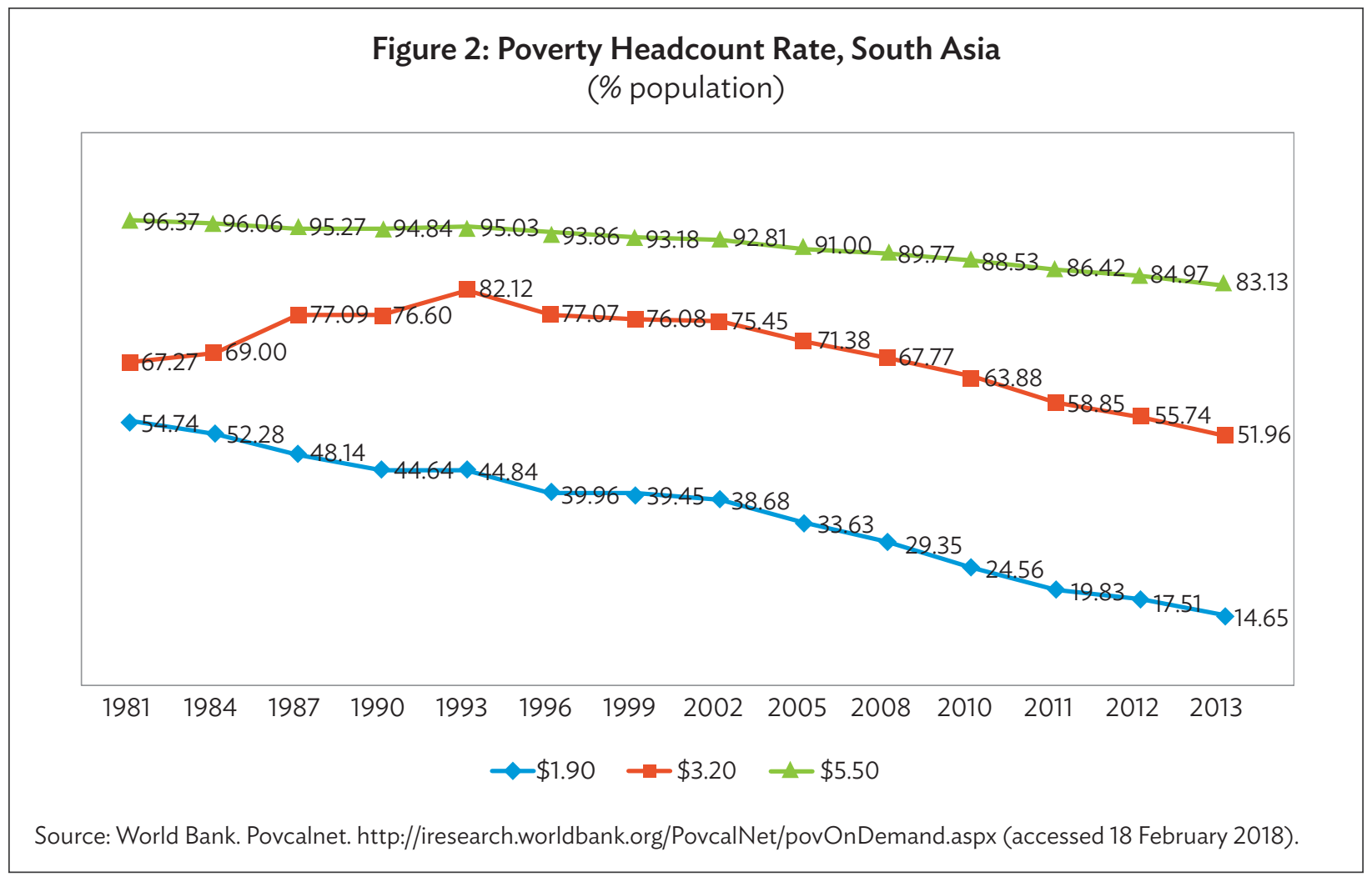

prospective policies that ensure their income security as well as access to quality health care. Social protection policies can play a significant role in addressing the demands of an older population and in facilitating changes to intergenerational patterns of care and support. ${ }^{11}$

7. There are large gaps in pension provision, especially among the low-income elderly population. The region's labor market liberalization has led to a decline in the share of the labor force contributing to pension schemes, especially among DMCs in Central Asia, which had originally managed to extend pension coverage to the majority of its labor force. ${ }^{12}$ Some DMCs, such as Nepal, Thailand, and Timor-Leste, are addressing pension coverage gaps through tax-financed transfers for older people, commonly described as social pensions. ${ }^{13}$

8. Where fertility rates have declined more slowly, as in India, a "youth bulge" has delayed the rise of old-age dependency rates, but at the costs of significant unemployment and underemployment among the young. Active labor market policies can be effective when directed at youth unemployment.

9. In addition, the high incidence of poverty among children is an urgent concern. A recent study by the World Bank disaggregated global extreme poverty by age and estimated that 328.7 million children live in extreme poverty globally, compared to 326.3 million adults (Table 1). Children under

11 S. W. Handayani and B. Babajanian. 2012. Social Protection for Older Persons: Social Pensions in Asia. Manila: ADB.

12 A. Barrientos. 2015. "Is There a Role for Social Pensions in Asia? Asia and the Pacific Policy Studies. 2 (1). pp. 8-20.

13 F. Gassmann. 2018. Social Assistance. In S. W. Handayani, ed. Asia's Fiscal Challenge: Financing the Social Protection Agenda of the Sustainable Development Goals. Manila: ADB. pp. 132-167. 
Table 1: Global Estimates of Children in Extreme Poverty by Region

\begin{tabular}{lccc}
\hline & $\begin{array}{c}\text { Children in Extreme Poverty } \\
\text { (millions) }\end{array}$ & $\begin{array}{c}\text { Child Headcount Poverty } \\
\text { Rate }\end{array}$ & $\begin{array}{c}\text { Share of Children in } \\
\text { Extreme Poverty }\end{array}$ \\
\hline East Asia Pacific & 25.6 & 5.6 & 7.8 \\
China, People's Republic of & 5.8 & 2.0 & 1.8 \\
South Asia & 117.2 & 19.5 & 35.7 \\
India & 99.7 & 22.1 & 30.3 \\
Sub-Saharan Africa & 170.0 & 48.7 & 51.7 \\
Latin America and the Caribbean & 14.3 & 8.1 & 4.4 \\
Europe and Central Asia & 1.3 & 1.4 & 0.4 \\
Total & 328.7 & 19.5 & 100.0 \\
\hline
\end{tabular}

Source: A. Castañeda, et al. 2018. A New Profile of the Global Poor. World Development. 101 (C). pp. 250-267.

age 18 years old constitute a majority among the global extreme poor. The same study estimated that 142.8 million children live in extreme poverty in South Asia, East Asia, and the Pacific, or 43.5\% of the total population. Addressing child extreme poverty and improving their chances to be healthy and educated is one of the most effective means to mitigate the adverse effects of population aging.

\section{Inclusive Growth}

10. Since the new century, growth in the region has not been as inclusive as in the 1980s and early 1990s. In the more populous DMCs, recent growth has been accompanied by rising inequality, reflecting economic and labor market conditions that are less auspicious for inclusive growth. As inclusive growth itself in the 1990 s compensated for deficiencies in social protection institutions and policies, the pattern of unequalizing growth in the 2000s is likely to magnify them. ${ }^{14}$

11. One analysis of changes in the Gini coefficient for selected DMCs noted that some (i.e., Fiji, Republic of Korea, Malaysia, Nepal, Philippines, and Thailand) have been associated with a reduction in inequality in the last 2 decades..$^{15}$ Growth in consumption and income has been larger, in relative terms, among the poorest income deciles. For most DMCs, especially the PRC, India, Indonesia, Lao People's Democratic Republic, Sri Lanka, and Viet Nam, recent growth has generated rising inequality, as the poorest income deciles suffered a contraction in their share of income or consumption relative to the two richest deciles in the population. Inequality rose in these DMCs because the poorest failed to benefit fully from growth.

14 R. Kanbur, C. Rhee, and J. Zhuang. 2014. Inequality in Asia and the Pacific: Trends, Drivers. and Policy Implications. Manila: ADB. Fiscal policy is a key part of the policy responses to rising inequality in Asia. Both government spending and taxation can affect inequality. Asian governments have ample room to maneuver in using fiscal policy to address the challenge of rising inequality, depending on individual country circumstances. This could involve increasing human capital investment and social protection provision-financing the increased spending on these through greater and more equitable revenue mobilization-and switching spending on inefficient general price subsidies (as for fuel) to targeted transfers (p. 81).

15 S. Jain-Chandra, et al. 2016. Sharing the Growth Dividend: Analysis of Inequality in Asia. International Monetary Fund (IMF) Working Papers. No. 16/48. Washington, DC: IMF. 
12. Income polarization describes conditions where the distribution of income is stretched out by economic trends; the Palma ratio is especially effective at showing this trend. ${ }^{16}$ The Palma ratio more than doubled from 1.0 to 2.1 in the PRC. ${ }^{17}$ It also rose in Indonesia, India, and the Philippines, but it declined in Malaysia from 3.0 to 2.6 and in Thailand from 2.5 to 1.8. This demonstrates a mixed picture for the region as a whole, but it raises important concerns for the nature of future growth and inequality.

13. The nature of recent economic growth in the region makes it imperative that DMCs pay close attention to their social protection systems, especially policies and programs directed to the least advantaged. Improvements in the scale of social protection and its effectiveness in delivering poverty and inequality reduction are necessary to make inclusive growth sustained and sustainable.

\section{Environmental Change}

14. Environmental change poses many challenges to sustainable growth and will likely intensify. The links existing between poverty reduction programs and climate change adaptation are just beginning to be studied, but it is undeniable that environmental change imposes an additional parameter on social protection policies in facilitating sustainable and inclusive growth.

15. The impact of climate change is not evenly distributed across DMCs and socioeconomic groups. ${ }^{18}$ Poorer DMCSs and poorer groups within DMCs will be more affected by climate change, for example, in the context of extreme weather events. As the region has historically shown greater exposure to extreme weather events, low-income groups often disproportionally suffer because they depend to a larger extent on natural resources, live in more vulnerable locations, and have low incomes that reduce their resilience.

16. Social protection has a twofold role; it needs to support disadvantaged groups in improving their resilience to climate change while fostering diversification of their livelihoods. Similarly, social assistance has an important role to play in ensuring positive environmental outcomes from poverty reduction and climate change adaptation. Improving consumption levels among disadvantaged groups, for example, will place additional pressures on energy consumption.

17. In rural areas, social protection can contribute to improving adaptive capacity where livelihoods are affected by climate change. It must support agricultural diversification and improve resilience, such as through complementary components of social assistance programs that provide support for natural resources management and sustainable food systems. The Bolsa Verde Program in Brazil and the Chars Livelihoods Program in Bangladesh, for example, deploy innovative approaches to combining poverty reduction and climate change adaptation.

16 The Palma ratio is the ratio of the share of income and consumption captured by the richest $10 \%$ of the population to the share of income and consumption captured by the poorest $40 \%$ of the population.

17 United Nations Economic and Social Commission for Asia and the Pacific. 2015. Time for Equality: The Role of Social Protection in Reducing Inequalities in Asia and the Pacific. Bangkok.

18 B. Laplante. 2010. Poverty, Climate Change, and the Economic Recession. In A. Bauer and M. Thant, eds. Poverty and Sustainable Development in Asia: Impacts and Responses to the Global Economic Crisis. Manila: ADB. 
18. The growth of cities in Asia and the Pacific provides a different set of challenges. Improvements in education, and girls' education in particular, are key to promoting long-term resilience. ${ }^{19}$ Social assistance has proven effective in facilitating improvements in schooling among children in low-income households.

\section{SOCIAL PROTECTION IN ASIA: TAKING STOCK}

\section{A. Spending}

19. According to data collected for the Social Protection Indicator, the regional average of social protection expenditure as a share of gross domestic product (GDP) shows a rise from just under $4.0 \%$ in 2003-2005 to 5.3\% in 2015. ${ }^{20}$ Although the expansion of social protection expenditure is welcome, the growth in expenditure on social protection is from a very low base. ${ }^{21}$

20. The share of social protection expenditure in total government expenditure helps assess the growing significance of the sector. Figure 3 shows a wide range in the share of social protection expenditure across selected DMCs in 2000 but a measure of convergence toward 2016. Bangladesh, India, the Kyrgyz Republic, Maldives, Mongolia, Tajikistan, and Thailand demonstrate large increases in the social protection sector's share of government expenditure, while Azerbaijan and Nepal actually demonstrate decreases. By 2016, social protection expenditure absorbs, on average, around one-fifth of government expenditure in the region.

\section{B. Programming}

21. Social protection includes three main components: social insurance, social assistance, and labor market interventions. Social insurance addresses life-course and employment-related contingencies, and is commonly financed by contributions from workers and their employers, but it also attracts large government subsidies. Social assistance is budget-financed and addresses poverty and vulnerability; it consists of transfers in cash and in kind to vulnerable households as well as social services. Labor market interventions combine legal measures protecting workers and active labor market policies enhancing the employability and productivity of the labor force and improving job information. Increasingly, employment policies for disadvantaged groups are integrated with social assistance programs. As a large and heterogeneous region, Asia and the Pacific provides numerous examples of recent initiatives in all social protection subcomponents. ${ }^{22}$

19 Footnote 18.

20 ADB figures from the Social Protection Indicator.

21 S. Jain-Chandra, et al. 2016. Sharing the Growth Dividend: Analysis of Inequality in Asia. IMF Working Papers. No. 16/48. Washington, DC: IMF.

22 C. Ong and C. Peyron Bista. 2015. The State of Social Protection in ASEAN at the Dawn of Integration. Geneva: International Labour Organization; and M. Honorati, U. Gentilini, and R. Yemtsov. 2015. The State of Social Safety Nets 2015. Washington, DC: World Bank Group. 


\section{Figure 3: Social Security and Welfare Spending, Asia and the Pacific}

(\% of government expenditure)

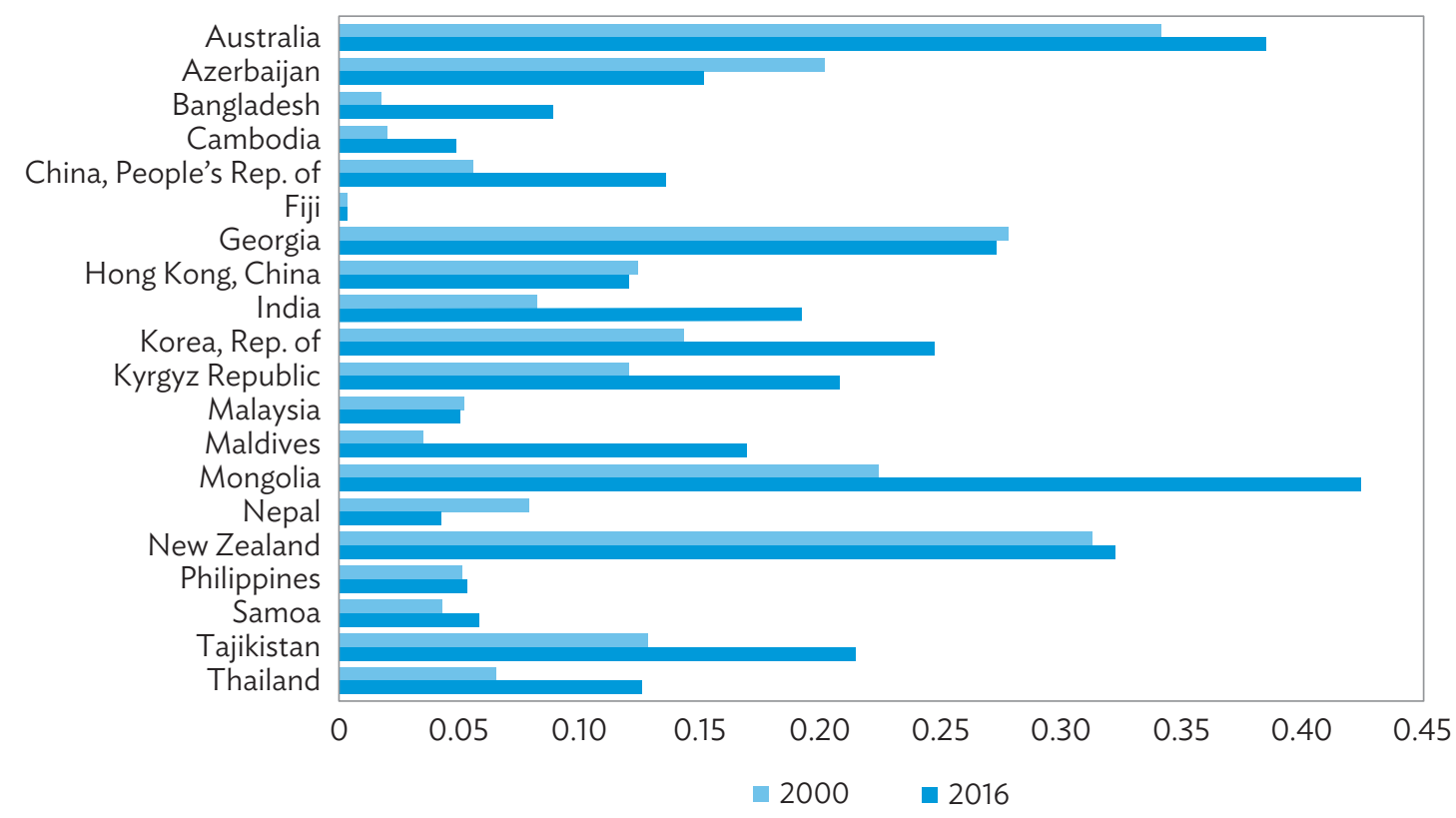

Source: ADB. 2016. Key Indicators for Asia and the Pacific 2016. Manila.

22. Social insurance. Some high- and middle-income DMCs have sought to extend social insurance to the majority of their populations. The PRC's pension schemes aim to ensure that all elderly persons have access to old-age pensions by encouraging workers to contribute to pension funds through large-scale government subsidies. Older people are offered access to pension benefits without a contribution history if their working-age children participate in the scheme. Thailand's Universal Health Coverage Scheme is another example of a budget-supported extension of social insurance. In middleand low-income countries where social insurance schemes cover a small share of the labor force in formal employment, recent initiatives have focused on improving the technical and financial components of pension schemes.

23. Social assistance. Large-scale, innovative social assistance schemes have emerged in many middle- and low-income DMCs (Appendix). The design and reach of these programs show important variations across DMCs and subregions. ${ }^{23}$

24. Income transfers to vulnerable groups have become the norm in middle-income countries, especially through the spread of family and old-age transfers. However, income transfers to families and children are rare in the region, with the exception of Mongolia's Child Money Programme. School stipends do exist, but they ignore early childhood and are not always focused on children living in poverty.

23 F. Gassmann. 2018. Social Assistance. In S. W. Handayani, ed. Asia's Fiscal Challenge: Financing the Social Protection Agenda of the Sustainable Development Goals. Manila: ADB. pp. 132-167; and A. Weber. 2009. Social Assistance in Asia and the Pacific: An Overview. In S. W. Handayani, and C. Burkley, eds. Social Assistance and Conditional Cash Transfers: Proceedings of the Regional Workshop. Manila: ADB. 
Income transfers to families in extreme poverty are even less common, except in Central Asia. ${ }^{24}$ Timelimited income transfers have been successfully employed in Indonesia to mitigate the adverse effects associated with the withdrawal of energy subsidies.

25. Social pensions have expanded across the region. ${ }^{25}$ Nepal introduced a transfer to the elderly, although starting at an advanced age. DMCs with existing social insurance pension schemes, mainly middle-income countries, have restricted social pensions to older people excluded from formal pension schemes or in poverty. There, social pensions are a means to complement existing provisions. Old-age transfers are popular among policy makers because they meet a variety of objectives, such as addressing the effects of migration and rapid urbanization, HIV/AIDS, and demographic change, while having predictable budgetary implications. ${ }^{26}$

26. Some DMCs have implemented conditional cash transfers, provided that children attend school and medical care. Large-scale programs are in place in Indonesia (Program Keluarga Harapan) ${ }^{27}$ and the Philippines (Pantawid Pamilyang Pilipino Program). ${ }^{28}$

27. Labor market interventions. Employment guarantee programs, of which India's Mahatma Gandhi National Rural Employment Guarantee is the largest example, secure a minimum income for disadvantaged families conditional on the supply of labor by adult members. ${ }^{29}$ Their design relies on selfselection by program participants. Entitlements are backed by legislation, and costs are included in the budgetary cycle. This is in contrast to public works, where entitlements are short-term and discretionary. Public works are more appropriately defined as emergency assistance.

\section{Reach}

28. The expansion of social assistance in Asia and the Pacific is in line with trends in other regions. Social assistance has expanded rapidly in Latin America and the Caribbean, and shows a rising trend in Africa from a very low base. Figure 4 shows the reach of social insurance and social assistance across developing regions. The values reflect the share of individuals in households with at least one participant in social insurance or social assistance, as defined by ASPIRE, estimated from household survey data.

29. The share of households reached by social insurance is very limited in South Asia and East Asia and the Pacific. Even in regions with a long-standing and sizeable social insurance component, such as Europe and Central Asia and Latin America and the Caribbean, the reach of social assistance is similar or greater than that of social insurance. Reaching a large share of the population that lacks access to any

24 F. Gassmann. 2011. Protecting Vulnerable Families in Central Asia: Poverty, Vulnerability and the Impact of the Economic Crisis. Innocenti Working Papers. No. 2011-05. Florence: United Nations Children's Fund (UNICEF) Research Office.

25 C. Knox-Vydmanov. 2017. Work, Family and Social Protection: Old Age Income Security in Bangladesh, Nepal, the Philippines, Thailand and Vietnam. Chiang Mai: HelpAge International.

26 S. W. Handayani and B. Babajanian. 2012. Social Protection for Older Persons: Social Pensions in Asia. Manila: ADB; B A. Barrientos. 2015. Is There a Role for Social Pensions in Asia? Asia and the Pacific Policy Studies. 2 (1). pp. 8-20.

27 V. Atalas. 2011. Program Keluarga Harapan: Impact Evaluation of Indonesia's Pilot Household Conditional Cash Transfer Program. Washington, DC: World Bank.

28 C. Reyes, A. Tabuga, C. Mina, and R. Asis. 2013. Promoting Inclusive Growth through the 4Ps. Philippine Institute for Development Studies (PIDS) Research Paper Series. No. RPS 2015-01. Quezon City: PIDS.

29 R. Khera, ed. 2001. The Battle for Employment Guarantee. Oxford: Oxford University Press. 


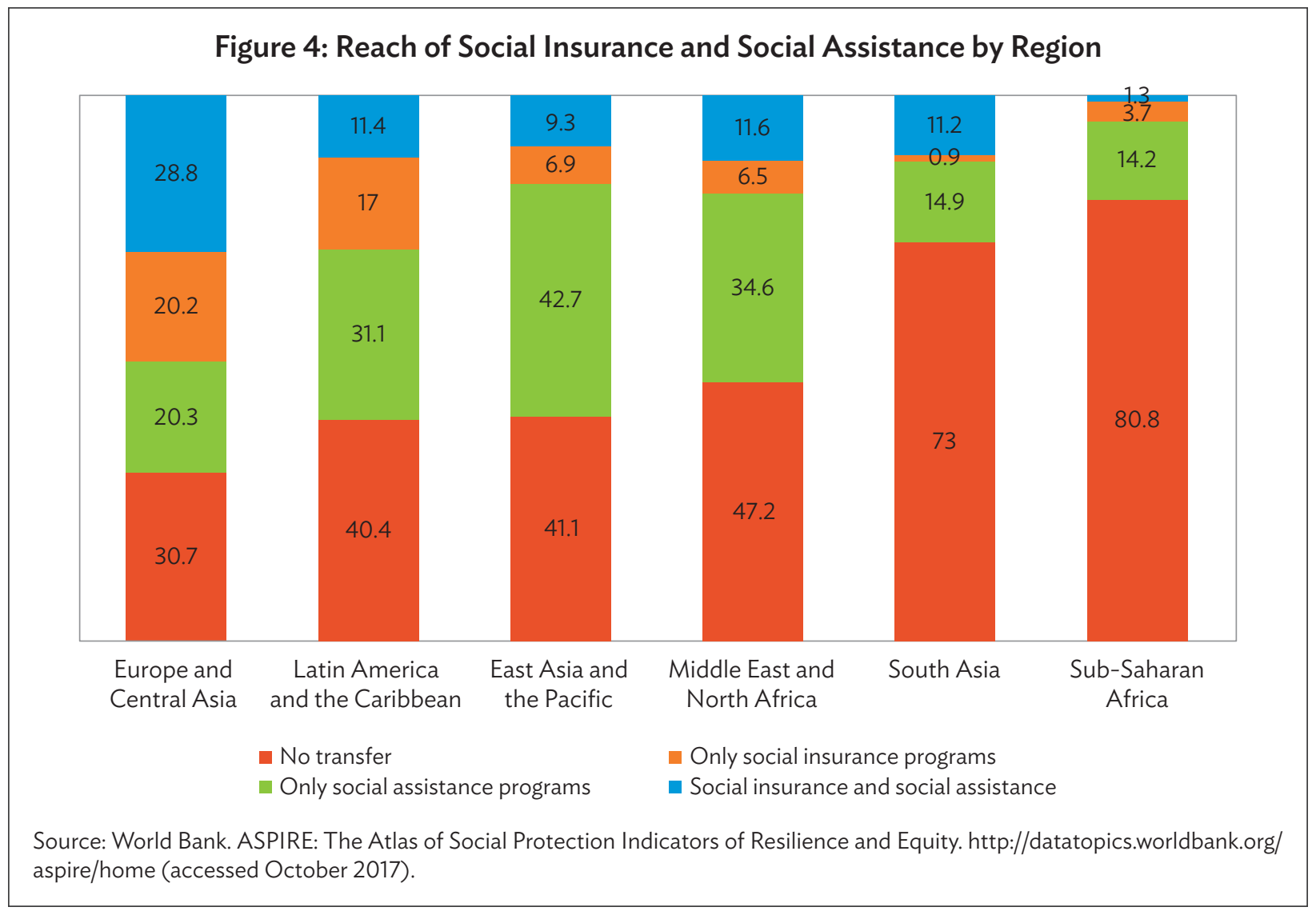

form of social protection (i.e., 73\% of the population in South Asia) must involve further expansion of budget-financed programs. ${ }^{30}$

30. The recent expansion of social assistance reflects efforts by governments in low- and middleincome countries to meet this challenge.

\section{Distribution}

31. ADB's Social Protection Indicator has raised key questions about the distribution of current social protection expenditure in the region. ${ }^{31}$ Social protection expenditure provides a measure of the aggregate resources available. The poverty reduction effectiveness of social protection-especially social assistance, programs, and policies-depends on the way that these resources are distributed to the population living in poverty. Figure 5 demonstrates that for the majority of DMCs, less than $20 \%$ of social protection spending supports those in poverty.

32. Social insurance accounts for the majority of social protection expenditure among DMCs, with pensions as the preferred instrument. Yet because social insurance schemes in DMCs reach only

30 M. Honorati, U. Gentilini, and R. Yemtsov. 2015. The State of Social Safety Nets 2015. Washington, DC: World Bank Group; and ILO. World Social Protection Report 2017-19: Universal Social Protection to Achieve the Sustainable Development Goals. Geneva.

31 ADB. 2019. The Social Protection Indicator for Asia: Assessing Progress. Manila. 
Figure 5: Social Protection and Social Assistance Expenditure Reaching the Poor, 2015

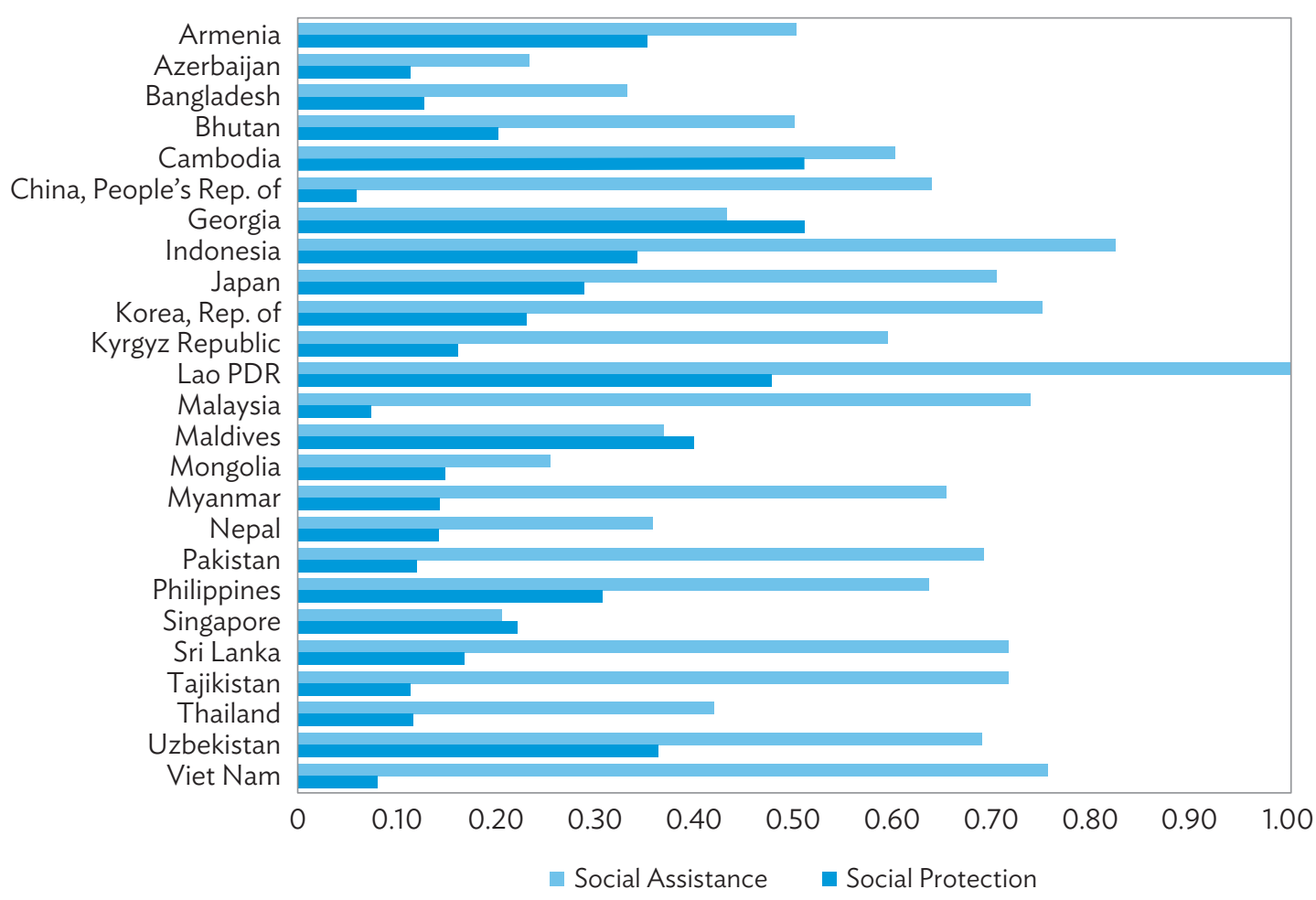

Lao PDR = Lao People's Democratic Republic.

Source: ADB. 2019. The Social Protection Indicator for Asia: Assessing Progress. Manila.

a small proportion of workers in formal employment, their distributional effects are limited, especially where social insurance relies on large public subsidies. An ADB study of the distributional effects of government spending found that the impact of additional spending on social protection increases inequality compared to spending on education or health. ${ }^{32}$ Social insurance schemes in DMCs seldom reach groups in poverty; as a consequence, their poverty reduction effectiveness is also limited.

33. Social assistance is targeted at disadvantaged groups and is expected to reduce poverty and vulnerability. At the same time, public subsidies to social assistance and social assistance transfers are typically less generous than social insurance transfers. It is a reasonable expectation that social assistance will thus be more effective in reducing poverty than in reducing aggregate inequality. Table 2 provides estimates of the contribution of social assistance to the reduction of poverty and inequality in selected DMCs.

34. The values confirm that social assistance has a stronger effect on poverty than on inequality. The contribution to the reduction of poverty is estimated in terms of the effect on the poverty headcount rate and poverty gap. Social assistance transfers are designed to make a contribution to household consumption but are insufficient to lift households above the poverty line. This explains why the estimated contribution to the reduction of the poverty gap is, in all cases, more substantial than the

32 I. Claus, J. Martínez-Vasquez, and V. Vulovic. 2012. Government Fiscal Policies and Redistribution in Asian Countries. Andrew Young School of Policy Studies Research Working Paper Series. No. 12-23. Atlanta: Georgia State University. 
Table 2: Social Assistance Contribution to Poverty and Inequality Reduction (\% change associated with all social assistance programs)

\begin{tabular}{lccc}
\hline & $\begin{array}{c}\text { Poverty Headcount } \\
\text { (P0) }\end{array}$ & $\begin{array}{c}\text { Poverty Gap } \\
\text { (P1) }\end{array}$ & Gini Coefficient \\
\hline Bangladesh, 2012 & 0.9 & 4.2 & 0.4 \\
China, People's Republic of, 2013 & 5.0 & 10.0 & 1.1 \\
Fiji, 2008 & 5.7 & 11.2 & 1.0 \\
Indonesia, 2015 & 16.9 & 38.2 & 4.6 \\
Kiribati, 2006 & 0.9 & 1.2 & 0.1 \\
Malaysia, 2008 & 6.3 & 13.3 & 1.3 \\
Maldives, 2009 & 11.7 & 27.9 & 3.9 \\
Micronesia, Federated States of, 2000 & 6.9 & 12.0 & 0.9 \\
Mongolia, 2012 & 34.7 & 52.9 & 10.3 \\
Nepal, 2010 & 4.8 & 7.2 & 0.7 \\
Pakistan, 2013 & 3.2 & 7.2 & 0.7 \\
Palau, 2006 & 0.8 & 1.8 & 0.1 \\
Philippines, 2015 & 8.8 & 15.2 & 1.5 \\
Solomon Islands, 2005 & 0.3 & 0.5 & 0.0 \\
Sri Lanka, 2012 & 4.1 & 9.1 & 0.9 \\
Thailand, 2013 & 11.5 & 21.1 & 2.6 \\
Viet Nam, 2014 & 10.9 & 4.2 & 0.4 \\
\hline
\end{tabular}

Note: Values compare poverty and inequality outcomes with and without social assistance programs. Estimations are based on household survey date from the year indicated.

Source: World Bank. ASPIRE: The Atlas of Social Protection Indicators of Resilience and Equity. http://datatopics.worldbank.org/aspire/ home (accessed October 2017]).

contribution to the reduction in the poverty headcount rate. Mongolia shows large social assistance effects on the Gini coefficient because of the scope and generosity of its social assistance transfers in 2012. In 2012, Mongolia's social assistance transfers reduced the poverty gap by one-half and the poverty headcount rate by one-third.

35. The variation in poverty and inequality outcomes across DMCs reflects the size, reach, and distribution of the social protection and social assistance budgets. Spending on social protection has shown an upward trend, focusing mainly on social assistance, in line with trends in Latin America and Africa. However, the distribution of growing spending is skewed toward nonpoor groups, restricting poverty reduction effectiveness.

\section{LOOKING AHEAD: STRENGTHENING SOCIAL ASSISTANCE AND THE ROLE OF ADB}

36. This section examines key issues likely to shape the development of social assistance and details the potential contribution of $A D B$ to this process. It will cover three main issues: the role of social assistance in improving the distributional properties of tax-transfer systems, alignment of social assistance protection and social investment objectives with programming, and requirement of sustainable financing. 


\section{A. Equity and Social Assistance: Tax-Transfer Systems}

37. The tax-transfer system is a powerful tool available to reduce inequality and poverty. Combining effective taxation with progressive public expenditure, fiscal policy is an essential foundation for inclusive growth through setting appropriate economic incentives, investing in basic services, and transferring resources to disadvantaged groups.

38. Tax-transfer systems in the region tend to be neutral in their effects on inequality. The Commitment to Equity (CEQ) Institute at Tulane University has studied some DMCs, analyzing the effect of their tax-transfer systems on their Gini coefficients. ${ }^{33}$ Figure 6 compares estimates of the Gini coefficient for different measures of income.

39. The study relied on household survey and administrative data to compose four measures of income. First, market income was calculated from the returns to the factors of production reported by households, then direct taxes and direct transfers were added to arrive at disposable income. Adding indirect subsidies and indirect taxes yielded a measure of consumable income, while an estimate of the value of basic public services was applied to households to arrive at final income. The Gini coefficient was then estimated for the different measures of income; changes in the Gini coefficient measure the effect of specific fiscal policies on inequality.

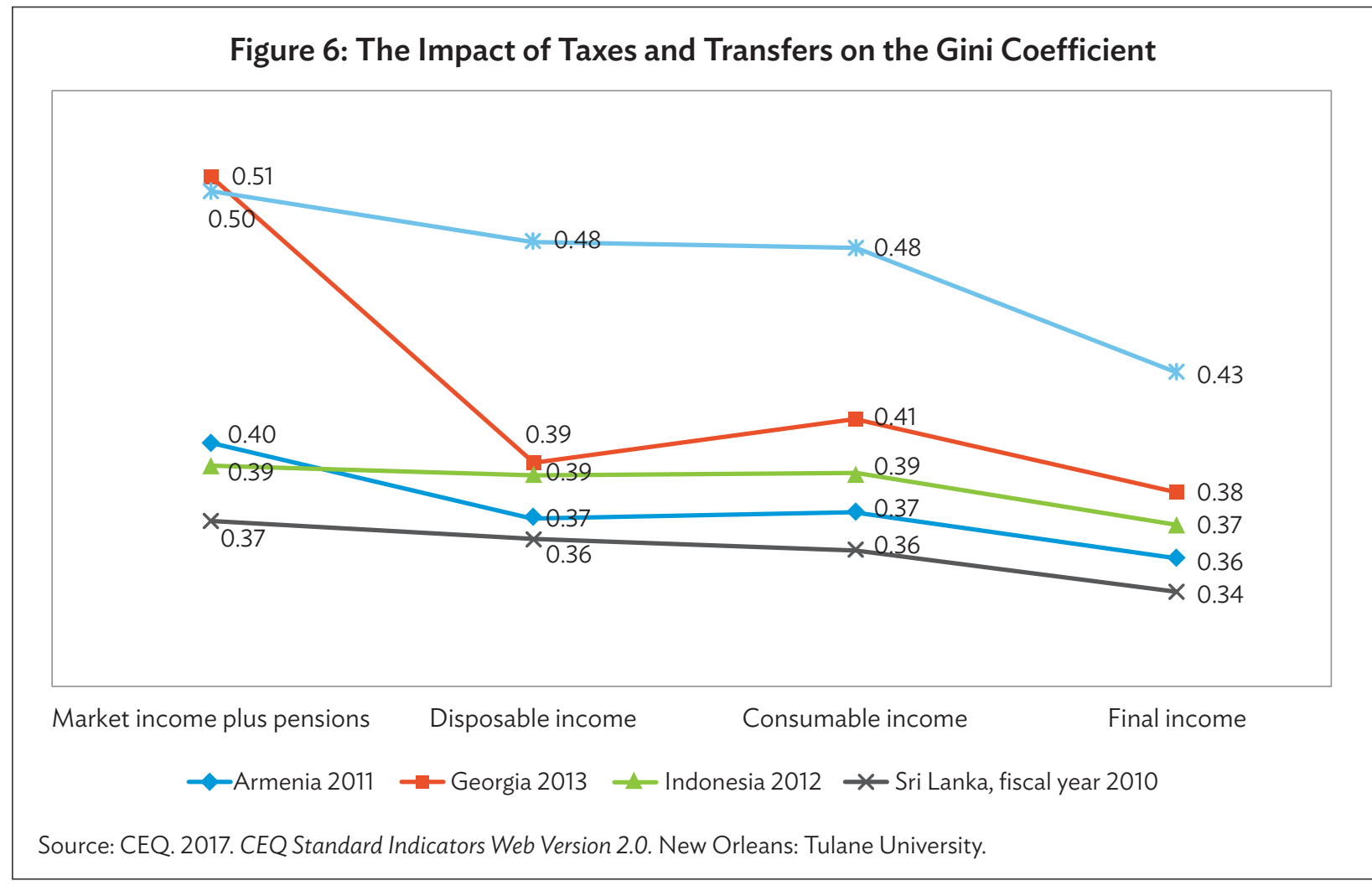

33 CEQ. 2017. CEQ Standard Indicators Web Version 2.0. New Orleans: Tulane University. 
40. As expected, direct taxes and transfers are expected to reduce inequality because personal income taxes are marginally progressive, but indirect subsidies and taxes show the opposite effect. Consumption taxes are a higher proportion of the incomes of disadvantaged groups than the betteroff. The provision of basic services has a significant equalizing effect, but care should be taken as the attribution of basic service public expenditure takes no account of variations in provision within urban and rural areas, for example.

41. Aside from Georgia, tax-transfer systems have little effect on inequality. In Georgia and Armenia, direct taxes and direct transfers have the largest effects on reducing inequality. The pattern shown by DMCs is similar to that of Latin America, although the latter shows higher baseline inequality. Success in addressing rising inequality makes it essential to improve the distributional properties of tax-transfer systems in the region.

42. In DMCs, taxes and transfers appear to have limited effects on poverty. Figure 7, again drawing on CEQ studies, compares poverty rates at the $\$ 2.50$ per day mark. ${ }^{34}$ It compares poverty headcount rates for different measures of income: market income, disposable income after direct transfers and taxes, and consumable income with the effects of indirect taxes and subsidies. Low-income households are unlikely to pay direct taxes, with the implication that the change in poverty moving from market to disposable income captures the effects of direct transfers, social insurance, and social assistance.

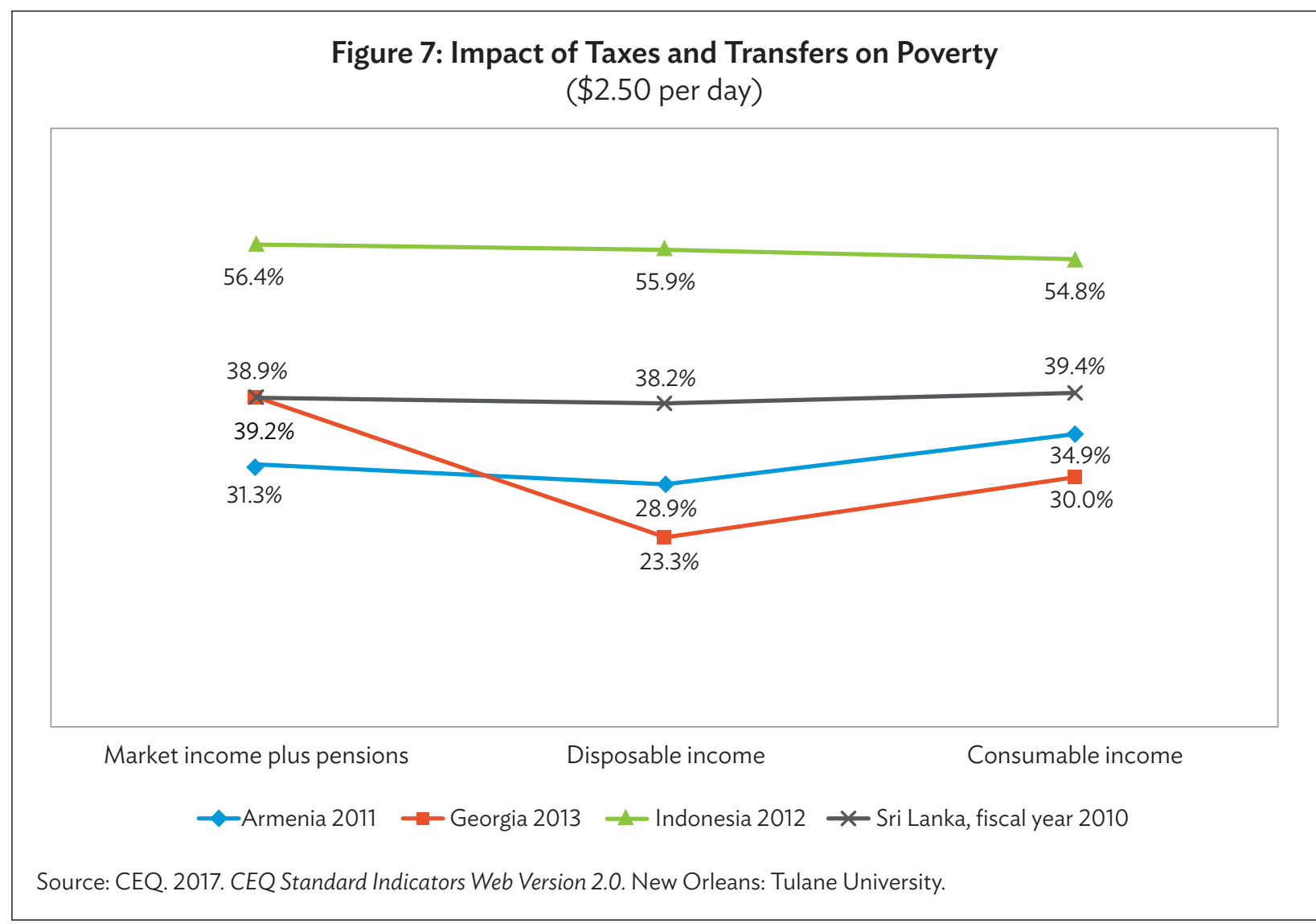

34 In 2005 United States dollars, equivalent to \$3.20 in 2011. 
43. In Georgia, direct transfers make a strong contribution to the reduction of poverty, but in other DMCs, they have marginal effects. With the exception of Indonesia, indirect taxes and subsidies actually raise the poverty headcount rate. In Armenia and Sri Lanka, the tax-transfer system, taken as a whole, increases poverty. In Indonesia and Georgia, it reduces poverty marginally. To the extent that these DMCs reflect conditions in other DMCs, improving the distributional properties of tax-transfer systems in the region requires raising the progressivity of direct transfers, that is, social assistance.

44. Expanding social assistance and focusing spending on low-income and informal groups can improve the distributional properties of tax-transfer systems in the region. ADB is well positioned to promote an understanding of social protection as an integral part of tax-transfer systems. In this respect, ADB can draw on the experience of high-income countries in the region to advise DMCs on the technical and policy issues involved in improving the distributional properties of tax-transfer systems.

\section{B. Aligning Objectives and Programming: Social Investment}

45. The global expansion of social assistance in low- and middle-income countries has emphasized its social investment role. Social assistance has a protective role in ensuring basic living standards as well as a social investment role in promoting improvements in productive capacity, especially education and health, among disadvantaged groups. Prior to the recent expansion of social assistance, its protective role was highlighted, targeting groups perceived to be especially vulnerable. Recent developments in social assistance programming, especially conditional cash transfers and employment guarantees, aim to balance protection with social investment, however.

46. Addressing poverty through consumption subsidies directed at disadvantaged households is essential in the short term. Sustainable exit from poverty requires strengthening the productive capacity of low-income and vulnerable households. This rebalancing of social assistance applies with equal force to low- and middle-income countries and to welfare states in high-income countries. ${ }^{35}$

47. Upgrading education and health outcomes is the most effective policy instrument to improve longer-term productivity; raising the human capital of children and youth is an especially effective form of social investment. Social assistance complements human development policies by ensuring that they reach disadvantaged groups. High returns to investment in children's schooling in low- and middle-income countries, for example, suggest well-designed and well-implemented social assistance interventions could pay for themselves (Box).

48. The timing of social investment is also important. The accumulation of skills is not linear through life, implying that early investment enhances the productivity of later investment in children's human development but late investment cannot always compensate for early gaps. ${ }^{36}$ The cost of recovering deficits in early human development investment can be high. Thus, the human development effects of alternative instruments must be noted. Social assistance programs that more directly focus on social investment, principally those focusing on families and children in poverty, can be expected to have stronger human development effects than employment guarantees or pure income transfers. However, these effects depend on the scope and implementation of programs as well as their context. Human development effects, therefore, must be assessed.

35 A. Hemerijck. 2012. Changing Welfare States. Oxford: Oxford University Press.

36 F. Cunha and J. Heckman. 2007. The Technology of Skill Formation. National Bureau of Economic Research (NBER) Working Papers. No. 12840. Washington, DC: NBER; and J. Heckman and D. Masterov. 2007. The Productivity Argument for Investing in Young Children. NBER Working Papers. No. 13016. Washington, DC: NBER. 


\section{Do Social Investment Programs Pay for Themselves?}

Participation in Brazil's Bolsa Escola programs, one of the earliest conditional income transfer programs and a core component of today's Bolsa Família, has improved school enrollment and attendance rates among children in participating households, demonstrating an 18\% increase in their education cycle or 1.5 additional years of education on average. An additional year of education may have raised wages in Brazil by around $11 \%$, implying an increase in labor earnings of $16 \%-17 \%$ among the poorest one-third of the population, or around $1.5 \%$ for the labor force taken as a whole. This is equivalent to an additional $0.8 \%$ of gross domestic product. Program costs are $0.4 \%$ of gross domestic product. Spreading the benefits over 40 years, the expected lifetime labor force participation in Brazil, and applying a $6 \%$ discount rate yield a net present value for the investment of $0.3 \%$. Other benefits and costs have not yet been fully taken into account, but it can be inferred that well-designed and well-implemented human development transfer programs pay for themselves.

Source: P. Glewwe and A. Kassouf. 2012. The Impact of Bolsa Escola/Bolsa Familia Conditional Cash Transfer Program on Enrollment, Dropout Rates and Grade Promotion in Brazil. Journal of Development Economics. 97. pp. 505-517.

49. Concerns that an emphasis on social investment may undermine the protective role of social assistance may be overstated in the context of low- and middle-income countries. For some groups, the protection dimension of social assistance is primary, such as for the elderly or people with disabilities. Yet the investment dimension is always present. Social pensions lead to improved health and schooling among children in pensioner households, while disability transfers will facilitate the schooling of children with disabilities. Well-designed social assistance ensures protection and investment are not substitutes but complements.

50. The broad picture that emerges from social assistance innovations and reforms is that DMCs have not paid sufficient attention to social investment. With a stronger social investment orientation, social assistance can make an important contribution to leveling inequality of opportunity by ensuring access to basic services and raising the productive capacity of disadvantaged groups. ADB is well positioned to draw its experience and expertise in advising DMCs on social assistance programming. The Social Protection Indicator is an essential tool for assessing social assistance in the region and identifying innovations and reforms. In influencing social assistance development, ADB can draw on its expertise in promoting a regional knowledge base through its support for regional and subregional networks, international conferences, publications, and country advisory services.

\section{Improving Technical and Implementation Capacity}

51. Social assistance provision would benefit from upgraded design and implementation capacity. Some steps have been taken by DMCs, but much more is needed. It is essential to approach recent reforms and innovation in social assistance in the region as emerging welfare institutions. Strengthening the institutional base of social assistance is needed to improve the stability and sustainability of financial support, as well as the legitimacy and effectiveness of social assistance programs.

52. The poverty reduction effectiveness of social assistance depends on the information available to executive agencies; information on the population likely to be affected by poverty is essential to the effectiveness of social assistance agencies. Persistent poverty affects a minority of households in the region, a share likely to fall with economic growth and social assistance expansion. However, above the persistent poor, a significant proportion of the population faces a positive probability of falling into poverty. Creation of registries of the population at risk is essential to induce effective policy responses. 
In contexts where programs addressing poverty are spread across several ministries and agencies, a single registry would help coordinate their efforts and generate savings from consolidating parallel and overlapping data collection activities. Currently, only a few DMCs have single registries, but a larger number are investing in information systems.

53. Limitations in implementation capacity also undermine the poverty reduction effectiveness of social assistance programs. For a majority of poor households, transfers in cash or in kind help them avoid further deterioration in their living standards, yet a minority may require tailored support and intermediation. Few DMCs are engaging in setting up direct support to these households, in large part because they lack resources and capacity to do so. The PRC has taken steps to improve such direct support to households, however.

54. Poverty reduction effectiveness can be improved by information on program implementation and outcomes. Technological change, and especially the digital revolution, can offer significant improvements in the implementation and monitoring of these programs. Monitoring provides real-time information, which is essential to fine-tune implementation. Moreover, the evaluation of outcomes contributes information to support policy decision making and accountability. Quasi-experimental impact evaluations of social assistance programs are helping generate a knowledge base, but developing a deep analysis of context is important to help generalize the findings from impact evaluations. The Social Protection Indicator is a good first step in developing a regional knowledge base.

55. Program outcome evaluations, at longer intervals, provide information on whether programs are achieving objectives and whether design reforms are needed. In the region, impact evaluations have been limited to programs providing transfers linked to asset accumulation, conditional cash transfers, and employment guarantees. They are rare in the context of other transfers, such as pensions or family and child transfers. Yet evaluating the poverty reduction effectiveness of existing programs yields the information necessary to maximize the returns from this investment. The region is behind others in the attention paid to evaluation. For example, one study on cash transfers performed a global search of impact evaluation studies and assessed their robustness. ${ }^{37}$ Asia and the Pacific is at a disadvantage in absolute and relative terms, with only a handful of evaluations available at the time of this study, mainly in Cambodia, Indonesia, and Pakistan, significantly fewer than those in sub-Saharan Africa and Latin America. Developing a knowledge base on social assistance outcomes is thus overdue in the region.

56. ADB is well placed to host a knowledge base on social assistance programs, their outcomes, and their evolution. As a membership-based regional body, ADB has the capacity to guide improvements in social assistance technical and implementation capacity in the interest of ADB members and to act as a repository of good practices.

\section{Sustainable Financing}

57. Over the last decade, social protection expenditure in the region shows an upward trend, but this cannot be generalized to all DMCs. ${ }^{38}$ In many, the resources assigned to social assistance are insufficient to maximize their poverty reduction effectiveness. At the same time, social protection and social assistance expenditures show significant variation over time (Figure 8). More DMCs show a contraction

37 F. Bastagli et al. 2016. Cash Transfers: What Does the Evidence Say? A Rigorous Review of Impacts and the Role of Design and Implementation Features. London: Overseas Development Institute. Annex 1: Overview of Existing Cash Transfer Reviews.

38 ADB. 2013. The Social Protection Index: Assessing Results for Asia and the Pacific. Manila. 


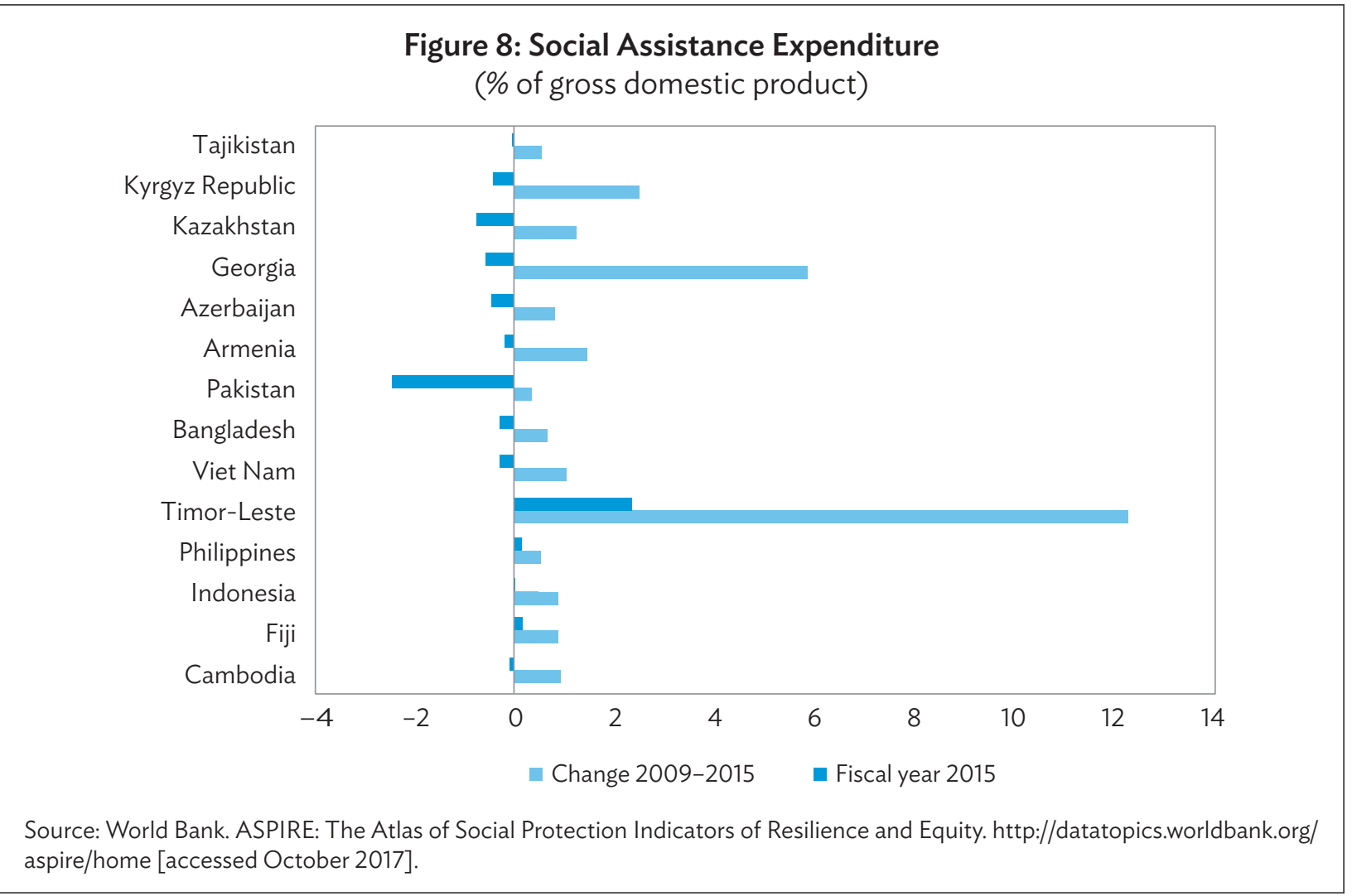

in expenditure, and the change in expenditure over time can be large. International aid currently plays a role in supporting low-income countries; with a few exceptions, donor funding supports institutional strengthening and pilot programs. In time, domestic financing should replace donor financing.

58. The financing issues facing DMCs are threefold: mobilizing additional resources to support social assistance, reducing the volatility in social assistance budgets, and shifting from international assistance to domestic financing in lower-income countries.

59. The restrictions on government revenue capacity in the region are well understood. DMCs have lower tax-GDP ratios than other regions. Broadening the tax base and improving tax administration are key to mobilizing additional resources. Improving the sustainability of social assistance provision, and budget stability over time, will be dependent on progressing the institutionalization of social assistance programs, especially their visibility in budgetary processes.

60. ADB's engagement with its members in the collection of statistics on government financial data provides a foundation and knowledge base to research the factors behind budgetary volatility. It is also well placed to identify lessons from country experiences and to disseminate these lessons through technical assistance and advice.

61. In sum, tax-transfer systems are the most effective public instrument to advance equity, but these systems as currently designed in DMCs have limited effects on equality and poverty. Social assistance has an important role in improving the distributional effects of tax-transfer systems in the 
region. The expansion of social assistance in low- and middle-income countries has emphasized its social investment role, but the balance of social assistance protection and social investment roles will be key to the development of social assistance in the region. Strengthening social assistance will require resource mobilization as well as sustainable and stable financing.

\section{CONCLUSION}

62. The expansion of social assistance provision in the region over the last 2 decades and its future development address a combination of long-standing and emerging challenges. The reduction in extreme poverty in the region has been remarkably successful, but large numbers remain in poverty and vulnerable conditions. Demographic change has accelerated, a consequence of the combination of extended life expectancy and a decline in fertility. Providing for an older population requires improving the productivity of younger groups. In addition, recent economic growth, in contrast to growth in the 1980s and 1990s, has not been inclusive, with inequality rising in more populous DMCs. This is a key challenge for social assistance. Environmental change provides an additional parameter in the design of social protection policy.

63. A brief assessment of current social assistance provision noted increased spending on social protection as a share of GDP and government expenditure. The latter underlines the increasing significance of the sector. The main focus of expansion has been on social assistance in line with trends in Latin America and Africa. The distribution of growing spending is skewed toward nonpoor groups in the population, however, limiting its poverty reduction effectiveness. With variation across countries, social assistance reduces poverty and inequality.

64. Three key issues are likely to shape the future development of social assistance in Asia and the Pacific. First, tax-transfer systems are the most effective public instrument to advance equity, but as currently designed, they have marginal effects on equality and poverty. Social assistance has an important role in improving the distributional effects of tax-transfer systems in the region. Second, the expansion of social assistance globally has emphasized its social investment role, but in Asia and the Pacific, its protective role is dominant. Rebalancing the protection and social investment roles of social assistance will be key to future developments. Third, strengthening social assistance will require resource mobilization as well as sustainable and stable financing. 


\section{The Role of Social Assistance in Reducing Poverty and Inequality in Asia and the Pacific}

This working paper analyzes the contribution of social protection-especially social assistance-in reducing poverty and inequality and supporting inclusive growth in Asia and the Pacific. The analysis is divided into three main sections. First, it reviews long-standing and emerging challenges to social protection in the region: poverty and inequality, demographic change, inclusive growth, and environmental change. Second, it reviews the provision of social assistance: spending, programming, reach, and distribution. Third, it examines key issues shaping the development of social assistance: equity, social investment, and sustainable financing.

\section{About the Asian Development Bank}

ADB is committed to achieving a prosperous, inclusive, resilient, and sustainable Asia and the Pacific, while sustaining its efforts to eradicate extreme poverty. Established in 1966, it is owned by 68 members -49 from the region. Its main instruments for helping its developing member countries are policy dialogue, loans, equity investments, guarantees, grants, and technical assistance. 